\title{
CORRELATION BETWEEN THE DAI AND ICON INDICES USED FOR ASSESSMENT OF ORTHODONTIC TREATMENT NEED IN CROATIAN SCHOOLCHILDREN KORELACIJA MED INDEKSOMA DAI IN ICON PRI VREDNOTENJU POTREBE PO ORTODONTSKEMU ZDRAVLJENJU PRI ŠOLOBVEZNIH OTROCIH NA HRVAŠKEM
}

\author{
Renata VIDAKOVIĆ ${ }^{1}$, Stjepan ŠPALJ², Mladen ŠLAJ1 ${ }^{1}$ Martina ŠLAJ1, Višnja KATIĆ2*
}

${ }^{1}$ University of Zagreb, School of Dental Medicine, Department of Orthodontics, Gundulićeva 5, 10000 Zagreb, Croatia

'University of Rijeka, School of Medicine, Department of Orthodontics, Krešimirova 40, 51000 Rijeka, Croatia

\section{ABSTRACT}

Keywords:

DAl index, ICON index, orthodontic treatment need, mixed dentition, permanent dentition, malocclusion prevalence

\section{IZVLEČEK}

Ključne besede: indeks DAl, indeks ICON, potreba po ortodontskem zdravljenju, menjalno zobovje, stalno zobovje, razširjenost malokluzije
Introduction: The aims were: evaluation of the correlation between the Dental Aesthetic Index (DAl) and Index of Complexity, Outcome and Need (ICON); the assessment of orthodontic treatment need for schoolchildren in a population with two indices, separately for schoolchildren with mixed and permanent dentition; the estimation of the population share that could not receive orthodontic treatment because of the presence of caries and/ or gingivitis.

Methods: A total of 2652 Zagreb school children (7 - 19 years old, $52.4 \%$ of them were females) completed a questionnaire regarding previous orthodontic treatment and the type of appliance used. Their oral cavity was also inspected. The DAI and ICON indices were used for the assessment of malocclusion prevalence.

Results: The subjects with mixed dentition had a greater need for orthodontic treatment, when compared to subjects with permanent dentition, when using the DAI index $(\mathrm{p}<0.001)$. When using the ICON index, $11.7 \%$ of subjects with mixed dentition had very severe malocclusion, as opposed to $5.8 \%$ of subjects with permanent dentition. The DAI and ICON scores correlated positively linearly $(r=0.521 ; p<0.001)$. A higher prevalence of both gingivitis and caries was recorded more often in boys; caries more often in the group with the mixed dentition, and gingivitis in the group with permanent dentition $(p<0.05)$.

Conclusion: The DAI and ICON indices have moderate agreement in assessment of malocclusion severity scores. One third of all schoolchildren with various degrees of both ICON and DAI indices have gingivitis, and half of them have caries.

Uvod: Cilji študije so: vrednotenje korelacije med indeksom estetskega videza zob (Dental Aesthetic Index, DAI) in indeksom zahtevnosti, izida in potrebe (Index of Complexity, Outcome and Need, ICON); vrednotenje potrebe po ortodontskem zdravljenju $v$ populaciji šoloobveznih otrok $z$ obema indeksoma, posamezna obravnava pri šoloobveznih otrocih z menjalnim in stalnim zobovjem; določanje deleža prebivalstva, ki ni prejela ortodontskega zdravljenja zaradi prisotnosti kariesa in/ali gingivitisa.

Metode: 2.552 učencev iz Zagreba (od 7. do 19. leta; od tega 52,4\% učenk) je izpolnilo vprašalnik o njihovem prejšnjem ortodontskem zdravljenju in vrsti zdravljenja, temu je sledil pregled ustne votline. Za vrednotenje razširjenosti malokluzije sta se uporabila indeksa DAI in ICON.

Rezultati: Učenci z menjalnim zobovjem imajo večjo potrebo po ortodontskem zdravljenju $v$ primerjavi $z$ učenci s stalnim zobovjem pri uporabi indeksa DAI $(p<0,001)$. Pri uporabi indeksa ICON je imelo $11,7 \%$ učencev z menjalnim zobovjem zelo resno in resno malokluzijo, učenci s stalnim zobovjem pa je 5,8\%. Rezultati indeksov DAl in ICON so medsebojno povezani pozitivno in linearno $(r=0,521 ; p<0,001)$. Večja razširjenost gingivitisa in kariesa je zabeležena pogosteje pri fantih, karies pa bolj pogosto $v$ skupini z menjalnim zobovjem, gingivitis pa $v$ skupini s stalnim zobovjem $(p<0,05)$.

Zaključek: Indeksa DAl in ICON se zmerno ujemata pri rezultatih vrednotenja resnosti malokluzije. Glede na različne stopnje indeksov DAI in ICON ima ena tretjina šoloobveznih otrok gingivitis, polovica pa karies. 


\section{INTRODUCTION}

Today, there are several indices being used in orthodontics, like the Dental Aesthetic Index (DAI) (1), the Peer Assessment Rating (PAR) (2), the Index of Complexity, the Outcome and Need (ICON) (3), the Index of Orthodontic Treatment Need (IOTN) (4). Indices in general were developed and employed for determination of the orthodontic treatment need in population, subsequent planning of an integrated public health solution, and evaluation of outcome of orthodontic treatment.

The DAl is often used in epidemiological studies, its use being accepted by the World Health Organisation (WHO) (5-7). This index gives an insight into the orthodontic treatment need from the point of view of socially acceptable aesthetic appearance of ten occlusal characteristics; and is also valid as a cross-cultural index (5-7). Many of the characteristics that give better insight into malocclusion severity (like the presence of cross bite, tooth impaction, mid-line shift or deep bite) are not accounted for with their specific weight in treatment need, and therefore generate discrepancies when compared to some other indices, as noted for the modified IOTN (8). The threshold for orthodontic treatment need can be modified according to the available financing and resources, as part of the public health program, and this is helpful in epidemiological studies (9-13). In Slovenia, for example, the Eismann-Farcnik index was developed and is currently been used for a comprehensive evaluation of an orthodontic treatment need, considering occlusal traits in deciduous, mixed and permanent dentition as well as the existence of a functional impairment (14).

On the other hand, the ICON measures orthodontic treatment complexity, outcome and need, giving more information about the specific case, but also considering the important aspect of dental aesthetics (3). A better understanding of malocclusion complexity helps better planning of the resources and funds needed for treatment, as well as the duration of treatment and the expected outcome. The ICON has also been accepted as a valid tool for use in epidemiological studies and is simple to use (8, 12-13, 15).

Previously, the comparison of the DAI and ICON indices has been investigated in studies that involved the evaluation of study casts by experienced examiners when using one or another index $(12,13)$. Those studies showed good reliability in assessing orthodontic treatment need with either of the indices employed; also, these indices were found to be valid for use in epidemiological studies (9-13, 15-17). Malocclusion assessment, recorded and measured intraorally, was found to be as reliable as the assessment on study casts (17). However, a significantly larger sample is required if comparisons between indices have to be made, as opposed to the sample sizes presented in previous studies $(10-13,15)$. Furthermore, none of the previous comparisons evaluated differences observed in indices' scores or categories, nor tried to converse malocclusion severity score from one index to another. The aims of this study were:

1. Evaluation of the correlation between the DAI and ICON indices employed,

2. Assessment of an orthodontic treatment need in schoolchildren population with the DAI and ICON indices, separately for schoolchildren with mixed and with permanent dentition,

3. Estimation of the population share that could not receive orthodontic treatment due to the presence of caries and/or gingivitis.

\section{SAMPLE AND METHODS}

This epidemiological cross-sectional survey involved a total of 2652 children and young adolescents in Zagreb, Croatia (5\% of Zagreb school children) (18). Subjects were between 7 and 19 years of age (median 15, inter-quartile range $12-16)$, and $52.4 \%$ of them were females. The initial sample size was considered adequate concerning the following parameters: around 100.000 schoolchildren in Zagreb, an expected prevalence of treatment need of $30 \%$, alpha type 1 error of $5 \%$ and confidence level of $95 \%$. Data was collected during an epidemiological survey lasting from September 2006 to February 2007. Examinees were selected in a cluster sampling procedure with special attention to administrative area for primary schools (107 schools in total) and the school type for secondary schools (55 schools in total). From each of four Zagreb's administrative areas three primary schools were randomly selected, and from each of three secondary school types (gymnasiums, technical, vocational) four schools were randomly selected. Intraoral measurements and questionnaires were administered upon written parental informed consent; participants aged 18 years and older provided their own written consent. The research has been conducted in full accordance with the World Medical Association Declaration of Helsinki. Individuals attending private and special needs schools, as well as those not attending any school, were excluded from this study.

The ICON and the DAl were used for assessment of orthodontic treatment need. Modified DAl scoring was used for assessment in subjects with mixed dentition (10). Both DAI and ICON indices use continuous scale based upon the regression equation to describe severity of one's malocclusion traits. DAI index takes into calculation of final score the following traits: tooth agenesis, spacing/ crowding, overjet, anterior open bite and occlusal sagittal relationship. The scores are grouped into four malocclusion categories $(\leq 25=$ Normal, $26-30=$ Definite, 
31-35=Severe, $\geq 36=$ Handicapping), which also describe treatment needs (in range from little or no need, elective need, highly desirable treatment to mandatory treatment) (1). ICON takes the Aesthetic Component (AC), crowding/spacing, cross bites, anterior open bite/ overbite, and sagittal posterior occlusion into calculation of final score. The AC has 10 colour photographs showing dentition in frontal view graded from 1 (most attractive) to 10 (least attractive). The final ICON score is divided into malocclusion complexity grades (<29=Easy, 2950=Mild; 51-63=Moderate, 64-77=Difficult, >77=Very difficult). A cut-off point of 43 was set to mark definite need for orthodontic treatment (3). A questionnaire was administrated for acquiring information on previous orthodontic treatment (choice of answers "yes/no") and the type of orthodontic appliance used (choice of answers "removable/fixed/both"). Examination of oral cavity included the assessment of periodontal health by Community Periodontal Index (CPI), and the caries experience by the sum of decayed, missing, and filled teeth (DMFT index) (19). The X-rays and study casts were not used during examination. Twenty examiners (orthodontic residents) were trained and calibrated for the inspection of oral cavity, for which they used the WHO's manual probe (19), a mouth mirror, and a forehead-mounted light lamp. Inter- and intra-examiners reproducibility was evaluated by the repeated measurements on ten examinees in oneweek interval, agreement proportion resulting in above $80 \%$ (intra-class correlation coefficient $r>0.87$, Cohen Kappa>0.64, p<0.001).

Statistical analysis used $\mathrm{x}^{2}$ test, Fisher's exact test, Kendall's tau-b coefficient, and regression analysis. All data was analysed in the SPSS 10.0 statistical software (SPSS Inc., Chicago, Illinois, USA), at $\mathrm{p}<0.05$ significance level.

\section{RESULTS}

\subsection{Assessment of the Orthodontic Treatment Need with the DAI and ICON Indices}

Based on the $x 2$ test, the subjects with mixed dentition had a greater need for orthodontic treatment, when compared to subjects with permanent dentition, when using the DAl index $(p<0.001)$, but with minor effect size (Kendall's $\tau-b=-0.131$ ), accounting for just $1.7 \%$ of the variability of orthodontic treatment need.

When using the ICON index, the subjects with mixed dentition had a more complex degree of malocclusion, when compared to the subjects with the permanent dentition $(p<0.001)$, with minor effect size (Kendall's $\tau-b=-0.163)$ of the dentition type on the prediction of an orthodontic treatment need. $11.7 \%$ of subjects with mixed dentition had very severe to severe malocclusion, opposed to $5.8 \%$ of subjects with permanent dentition.
When the ICON limit for orthodontic treatment need (cut-off point at 43) was set, the subjects with mixed dentition needed orthodontic treatment more often, when compared to the subjects with permanent dentition (34\% vs. 18\%; $p<0.001$ ). Still, the effect size was minor (Kendall's $\tau-b=-0.163$ ). Mixed dentition was associated with almost two times greater chance for orthodontic treatment need $(\mathrm{OR}=1.96 ; 95 \% \mathrm{Cl}=1.68-2.29)$.

\subsection{Correlation between the DAI and ICON Indices}

The DAI and the ICON score (expressed as variables on the continuous scale) demonstrated moderate positive linear correlation $(r=0.521 ; p<0.001)$, with stronger correlation for the subjects with permanent dentition $(r=0.516$; $\mathrm{p}<0.001$ ), when compared to the subjects with mixed dentition $(r=0.493 ; p<0.001)$. The prediction equations (Figure 1) enabled calculation of the ICON score via acquired DAI score, separately for mixed and permanent dentition, and vice versa.

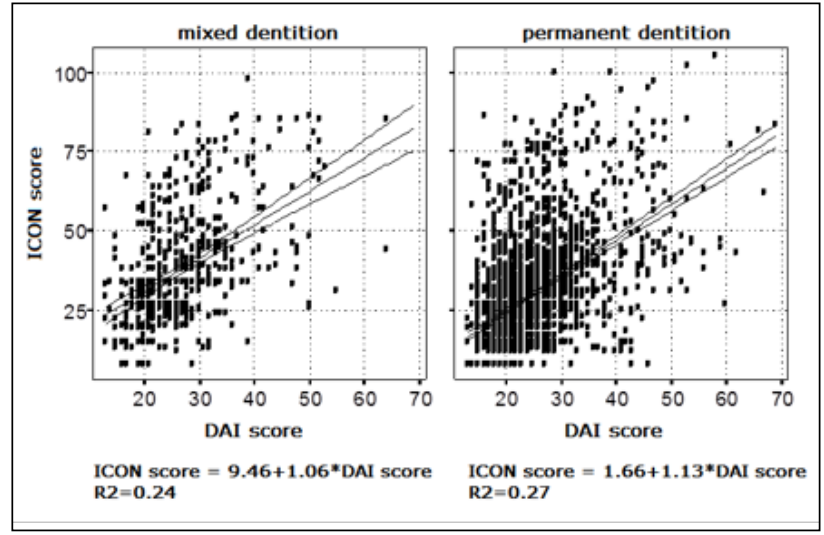

Figure 1. The prediction equations for calculation of the ICON score via acquired DAI score, separately for mixed and permanent dentition.

The DAI and ICON categories correlated positively moderately, the correlation being weaker for the subjects with mixed dentition, when compared to the subjects with permanent dentition ( $\tau-b=0.367$ vs. $0.426 ; p<0.001)$, accounting for $13.5 \%$ and $18.2 \%$ of the variability. The differences in the distribution of ICON categories within every DAl category were significant for the " 0 " and " 3 " DAl categories $(p<0.05)$, in subjects with both mixed and permanent dentition.

The DAI categories and the ICON divisions for orthodontic treatment need (cut-off point at 43) correlated positively moderately, with the stronger effect for the subjects with permanent dentition, when compared to those with mixed dentition $(\tau-b=0.347$ vs. $0.313 ; p<0.001)$. Significant differences in the distribution of the ICON divisions within 
Table 1. Distribution of the ICON degrees with cut-off point of 43 between dentition types within the DAl categories $(0=$ Normal, $1=$ Definite, 2=Severe, 3=Handicapping).

\begin{tabular}{|c|c|c|c|c|c|c|c|c|}
\hline \multirow{2}{*}{$\begin{array}{l}\text { DAI } \\
\text { categories }\end{array}$} & \multirow{2}{*}{$\begin{array}{l}\text { Dentition } \\
\text { type }\end{array}$} & & \multicolumn{2}{|c|}{ ICON cut-off point of 43} & \multirow[t]{2}{*}{ Total } & \multirow[t]{2}{*}{$\mathrm{p}^{*}$} & \multirow[t]{2}{*}{ OR $(95 \% \mathrm{Cl})$} & \multirow[t]{2}{*}{$\tau-b$} \\
\hline & & & $\begin{array}{c}\text { No treatment } \\
\text { need }\end{array}$ & $\begin{array}{c}\text { Treatment } \\
\text { needed }\end{array}$ & & & & \\
\hline \multirow[t]{6}{*}{0} & Mixed & $\mathrm{N}$ & 179 & 48 & 227 & & & \\
\hline & & $\%$ & 78.9 & 21.1 & 100.0 & & & \\
\hline & Permanent & $\mathrm{N}$ & 1265 & 115 & 1380 & & & \\
\hline & & $\%$ & 91.7 & 8.3 & 100.0 & $<0.001$ & $2.54(1.87-3.45)$ & -0.148 \\
\hline & Total & $\mathrm{N}$ & 1444 & 163 & 1607 & & & \\
\hline & & $\%$ & 89.9 & 10.1 & 100.0 & & & \\
\hline \multirow[t]{6}{*}{1} & Mixed & $\mathrm{N}$ & 79 & 36 & 115 & & & \\
\hline & & $\%$ & 68.7 & 31.3 & 100.0 & & & \\
\hline & Permanent & $\mathrm{N}$ & 277 & 94 & 371 & 0.228 & $1.24(0.90-1.71)$ & -0.057 \\
\hline & & $\%$ & 74.7 & 25.3 & 100.0 & & & \\
\hline & Total & $\mathrm{N}$ & 356 & 130 & 486 & & & \\
\hline & & $\%$ & 73.3 & 26.7 & 100.0 & & & \\
\hline \multirow[t]{6}{*}{2} & Mixed & $\mathrm{N}$ & 29 & 38 & 67 & & & \\
\hline & & $\%$ & 43.3 & 56.7 & 100.0 & & & \\
\hline & Permanent & $\mathrm{N}$ & 110 & 68 & 178 & & & \\
\hline & & $\%$ & 61.8 & 38.2 & 100.0 & 0.014 & $1.49(1.12-1.97)$ & -0.167 \\
\hline & Total & $\mathrm{N}$ & 139 & 106 & 245 & & & \\
\hline & & $\%$ & 56.7 & 43.3 & 100.0 & & & \\
\hline \multirow[t]{6}{*}{3} & Mixed & $\mathrm{N}$ & 24 & 44 & 68 & & & \\
\hline & & $\%$ & 35.3 & 64.7 & 100.0 & & & \\
\hline & Permanent & $\mathrm{N}$ & 92 & 99 & 191 & & & \\
\hline & & $\%$ & 48.2 & 51.8 & 100.0 & 0.088 & $1.25(0.99-1.56)$ & -0.114 \\
\hline & Total & $\mathrm{N}$ & 116 & 143 & 259 & & & \\
\hline & & $\%$ & 44.8 & 55.2 & 100.0 & & & \\
\hline
\end{tabular}

*Fischer exact test

the " 0 " and " 2 " DAl categories were found for both mixed and permanent dentition $(p<0.05$, Table 1$)$.

\subsection{Assessment of Orthodontic Treatment Need in Schoolchildren, Regarding Previous Orthodontic Treatment}

In total $67.7 \%$ of Zagreb schoolchildren never received orthodontic treatment, $84.5 \%$ of them with mixed dentition and $63.9 \%$ with permanent dentition.

During examination, $12.2 \%$ of the subjects were undergoing orthodontic treatment with removable appliances (8.7\% with mixed dentition, $13 \%$ with permanent dentition). At the same time, $3.3 \%$ of the subjects were treated with fixed appliances $(1 \%$ with mixed dentition, $3.8 \%$ with permanent dentition).
The subjects with orthodontic treatment history showed no differences in the current need for orthodontic treatment, when compared to the subjects without previous orthodontic treatment, regardless of the dentition type (ICON cut-off point at 43, Table 2). 
Table 2. Distribution of orthodontic treatment need in schoolchildren who were not undergoing orthodontic treatment at the time of the study, with respect to dentition type and previous orthodontic treatment, with the ICON cut-off point of 43.

\begin{tabular}{|c|c|c|c|c|c|c|}
\hline \multirow{2}{*}{$\begin{array}{l}\text { Dentition } \\
\text { type }\end{array}$} & \multirow{2}{*}{$\begin{array}{l}\text { Previous } \\
\text { treatment }\end{array}$} & & \multicolumn{2}{|c|}{ ICON cut-off point of 43} & \multirow[t]{2}{*}{ Total } & \multirow[t]{2}{*}{ p } \\
\hline & & & \multicolumn{2}{|c|}{ No treatment need Treatment needed } & & \\
\hline \multirow[t]{6}{*}{ Mixed } & No & $\mathrm{N}$ & 264 & 136 & 400 & \\
\hline & & $\%$ & 66.0 & 34.0 & 100.0 & \\
\hline & Yes & $\mathrm{N}$ & 17 & 11 & 28 & 0.545 \\
\hline & & $\%$ & 60.7 & 39.3 & 100.0 & \\
\hline & Total & $\mathrm{N}$ & 281 & 147 & 428 & \\
\hline & & $\%$ & 65.7 & 34.3 & 100.0 & \\
\hline \multirow[t]{6}{*}{ Permanent } & No & $\mathrm{N}$ & 1115 & 236 & 1351 & \\
\hline & & $\%$ & 82.5 & 17.5 & 100.0 & \\
\hline & Yes & $\mathrm{N}$ & 326 & 79 & 405 & 0.376 \\
\hline & & $\%$ & 80.5 & 19.5 & 100.0 & \\
\hline & Total & $\mathrm{N}$ & 1441 & 315 & 1756 & \\
\hline & & $\%$ & 82.1 & 17.9 & 100.0 & \\
\hline
\end{tabular}

*Fischer exact test

The tendency towards a greater need for orthodontic treatment was observed among previously treated subjects in both dentition type groups (Table 3).

Table 3. Distribution of the ICON categories ( $0=$ Easy, $1=$ Mild, $2=$ Moderate, $3=$ Difficult, $4=$ Very Difficult) in schoolchildren who were not undergoing orthodontic treatment at the time of the study, with respect to dentition type and previous orthodontic treatment.

\begin{tabular}{|c|c|c|c|c|c|c|c|c|c|}
\hline \multirow{2}{*}{$\begin{array}{l}\text { Dentition } \\
\text { type }\end{array}$} & \multirow{2}{*}{$\begin{array}{l}\text { Previous } \\
\text { treatment }\end{array}$} & & \multicolumn{5}{|c|}{ ICON complexity } & \multirow[t]{2}{*}{ Total } & \multirow[t]{2}{*}{$\mathrm{p}^{*}$} \\
\hline & & & 0 & 1 & 2 & 3 & 4 & & \\
\hline \multirow[t]{6}{*}{ Mixed } & No & $N$ & 143 & 166 & 47 & 23 & 21 & 400 & \\
\hline & & $\%$ & 35.8 & 41.5 & 11.8 & 5.8 & 5.3 & 100.0 & \\
\hline & Yes & $N$ & 10 & 10 & 5 & 2 & 1 & 28 & \\
\hline & & $\%$ & 35.7 & 35.7 & 17.9 & 7.1 & 3.6 & 100.0 & 0.870 \\
\hline & Total & $\mathrm{N}$ & 153 & 176 & 52 & 25 & 22 & 428 & \\
\hline & & $\%$ & 35.7 & 41.1 & 12.1 & 5.8 & 5.1 & 100.0 & \\
\hline \multirow[t]{6}{*}{ Permanent } & No & $N$ & 737 & 469 & 72 & 45 & 28 & 1351 & \\
\hline & & $\%$ & 54.6 & 34.7 & 5.3 & 3.3 & 2.1 & 100.0 & \\
\hline & Yes & $N$ & 221 & 129 & 27 & 17 & 11 & 405 & 0.561 \\
\hline & & $\%$ & 54.6 & 31.9 & 6.7 & 4.2 & 2.7 & 100.0 & \\
\hline & Total & $\mathrm{N}$ & 958 & 598 & 99 & 62 & 39 & 1756 & \\
\hline & & $\%$ & 54.6 & 34.1 & 5.6 & 3.5 & 2.2 & 100.0 & \\
\hline
\end{tabular}

${ }^{*} \mathrm{X}^{2}$ test 
Previously treated subjects with permanent dentition more often had a higher degree of malocclusion, when compared to the untreated subjects, when using the DAI categories $(p=0.032$, Table 4$)$.

Table 4. Distribution of the DAl categories ( $0=$ Normal, $1=$ Definite, $2=$ Severe, $3=$ Handicapping) in schoolchildren who were not undergoing orthodontic treatment at the time of the study, with respect to previous orthodontic treatment.

\begin{tabular}{|c|c|c|c|c|c|c|c|c|}
\hline \multirow{2}{*}{$\begin{array}{l}\text { Dentition } \\
\text { type }\end{array}$} & \multirow{2}{*}{$\begin{array}{l}\text { Previous } \\
\text { treatment }\end{array}$} & & \multicolumn{4}{|c|}{ ICON complexity } & \multirow[t]{2}{*}{ Total } & \multirow[t]{2}{*}{$\mathrm{p}^{*}$} \\
\hline & & & 0 & 1 & 2 & 3 & & \\
\hline \multirow[t]{6}{*}{ Mixed } & No & $N$ & 191 & 104 & 54 & 60 & 409 & \\
\hline & & $\%$ & 46.7 & 25.4 & 13.2 & 14.7 & 100.0 & \\
\hline & Yes & $N$ & 18 & 5 & 2 & 3 & 28 & \\
\hline & & $\%$ & 64.3 & 17.9 & 7.1 & 10.7 & 100.0 & 0.343 \\
\hline & Total & $N$ & 209 & 109 & 56 & 63 & 437 & \\
\hline & & $\%$ & 47.8 & 24.9 & 12.8 & 14.4 & 100.0 & \\
\hline \multirow[t]{6}{*}{ Permanent } & No & $N$ & 925 & 243 & 109 & 97 & 1374 & \\
\hline & & $\%$ & 67.3 & 17.7 & 7.9 & 7.1 & 100.0 & \\
\hline & Yes & $N$ & 265 & 70 & 31 & 48 & 414 & \\
\hline & & $\%$ & 64.0 & 16.9 & 7.5 & 11.6 & 100.0 & 0.032 \\
\hline & Total & $N$ & 1190 & 313 & 140 & 145 & 1788 & \\
\hline & & $\%$ & 66.6 & 17.5 & 7.8 & 8.1 & 100.0 & \\
\hline
\end{tabular}

${ }^{*} x^{2}$ test

\subsection{Estimation of the Population Share that could not Receive Orthodontic Treatment due of the Presence of Caries and/or Gingivitis}

Subjects had carious teeth more often in the mixed dentition group, when compared to the subjects with permanent dentition, but the association was weak $(p<0.001, \tau-b=-0.082)$ with minor effect size. There was $a$ 1.08 times greater chance for caries in the mixed dentition group, opposed to the permanent dentition group $(95 \% \mathrm{Cl}$ 1.04-1.12).
Gingivitis occurred more often in the permanent dentition group, although the association is weak $(p<0.001$; $\tau-b=0.095)$. There was a 1.64 times greater chance for gingivitis in the permanent dentition group, when compared to the mixed dentition group (95\% $\mathrm{Cl} 1.33-2.01)$. Figure 2 shows the distribution of gingivitis and caries according to the dentition types. Both gingivitis and caries were found more often in boys, caries more often in the mixed dentition group, and gingivitis in the permanent dentition group $(p<0.05)$. Girls more often fulfilled the criteria for enrolment in orthodontic treatment in both mixed (39\% vs. $32 \%)$ and permanent dentition (42.2\% vs. $36.9 \%)$, all at $p<0.05$.

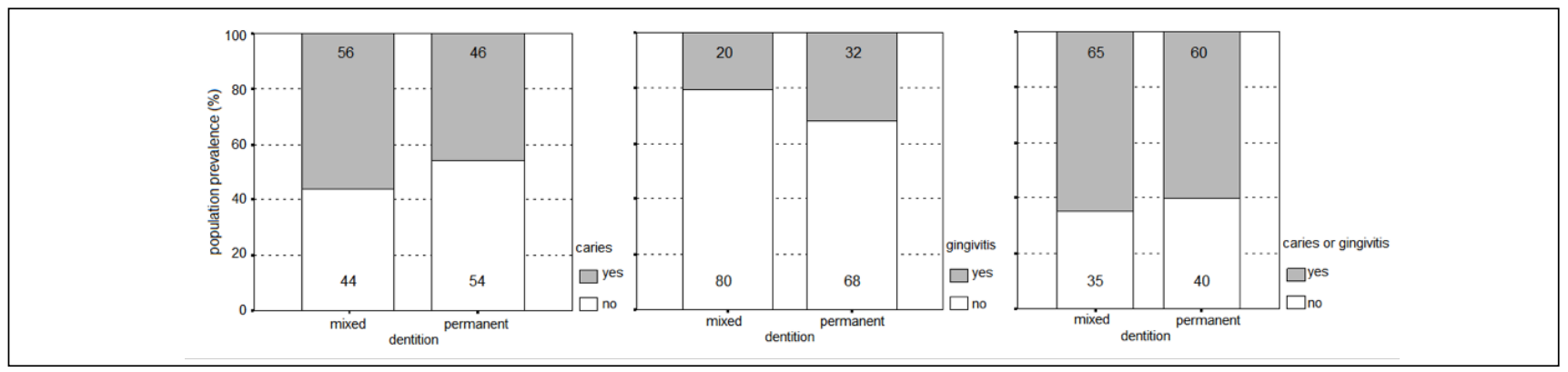

Figure 2. Distribution of gingivitis and caries in the population, separately for schoolchildren in mixed and permanent dentition. 
Between $50 \%$ and $66.2 \%$ of schoolchildren did not meet the criteria for enrolment in orthodontic treatment due to caries, for the DAI malocclusion degrees $\geq 1$ or ICON 43 cases.

Between $51 \%$ and $66 \%$ of previously untreated subjects with the ICON categories $\geq 2$ did not meet the criteria for enrolment in orthodontic treatment due to caries.

At ICON cut-off value of $43,62.1 \%$ of the previously untreated schoolchildren did not meet the criteria for enrolment in orthodontic treatment due to caries $(64.7 \%$ subjects with mixed dentition vs. $60.6 \%$ subjects with permanent dentition), and $33 \%$ of them had gingivitis (40.9\% with permanent dentition vs. $19.9 \%$ with mixed dentition).

One third of all subjects with various degrees of both the ICON and DAI indices had gingivitis as the excluding criteria for enrolment in orthodontic treatment.

\section{DISCUSSION}

The results showed that the DAI and ICON indices showed moderate correlation in the intraoral assessment of orthodontic treatment need with slightly higher correlation among schoolchildren with permanent dentition, when compared to the schoolchildren with mixed dentition. Conversion of the malocclusion severity score from one index to another could be made by here presented regression equation. This linear regression accounts for up to the $27 \%$ of the variability.

Previous research suggested that the ICON could replace the PAR and IOTN (15), since the ICON was developed from the PAR and IOTN, and correlated highly with both of these indices. Another study found good agreement between the ICON and the dental health component (DHC) of the IOTN, and moderate agreement with the aesthetic component of the IOTN, suggesting that the ICON could substitute the DHC IOTN (19). Still, the ICON is primarily focused on space problems in maxillary arch, and this contributes to disparity in its comparison to other indices.

Results also showed that one in six schoolchildren with permanent dentition is in need for orthodontic treatment; the need is greater in schoolchildren with mixed dentition and in previously treated schoolchildren with permanent dentition. Also, previously untreated schoolchildren with mixed dentition have greater need for orthodontic treatment, when compared to the previously treated schoolchildren. Generally, schoolchildren with severe malocclusions were enrolled in orthodontic treatment, but the real concern comes from the cognition that the schoolchildren with the most severe malocclusions had already previously received orthodontic treatment.
At the time of the study, the national health insurance fund made orthodontic care available free of costs to all schoolchildren, regardless of their malocclusion severity. These limitless treatments had the unpredictably high overall costs, and still did not contribute to reduction of the population share with severe malocclusions. The data on residual treatment need obtained from this study urge for better planning of future costs, considering prevalence of treatment need in population and establishing criteria for enrolment in orthodontic therapy. Suitable threshold value for the DAl index could be established in accordance with the projection of treatment costs and funding available for orthodontic treatment within the state insurance fund, taking into account the DAI results from this study. The ICON supplied data about malocclusions complexity, expected treatment duration and outcome; all of which are important factors in the financial planning and evaluation of treatment results, and here presented results give useful information for the health care reform planning. Present study does not give reasons for the high share of severe malocclusions in already treated patients, those lie probably both in patients' drop-outs as well as in inappropriate treatment plan. Our study showed that schoolchildren enrolled in orthodontic treatment were four times more often treated with some type of removable appliance, compared to treatment with fixed appliances. Treatment with removable appliances are dependant more on the patients' cooperation, and are often combined with subsequent fixed appliance in order to achieve better aesthetics and lessen the severity of the malocclusion. High share of severe malocclusions in already treated schoolchildren calls for evaluation of treatment results, and possibly for treatment options that rely less on patients compliance. It was found that both children and their parents are prone to under-assess their malocclusion severity and treatment need, which could contribute to the increase in drop-out rate (21-24).

The percentage of schoolchildren that have either decay or gingivitis was high, indicating the need for better oral health care, oral hygiene education and prevention programs. Also, general dentists in Croatia frequently avoid curing caries on deciduous teeth and refer patients to an orthodontic consultation with active carious lesions (25). Caries can contribute to the development of malocclusions, especially in midline shift problems; extractions caused by severely decayed teeth and loss of space in dental arches result in crowding $(26,27)$. As $56 \%$ of schoolchildren with mixed dentition and $46 \%$ of schoolchildren with permanent dentition have caries, one can assume that the overall orthodontic treatment need in population might be lowered if caries prevention and timely treatment were employed (27). Recent research showed strong correlation between the oral health and 
number of preserved teeth and self-reported general health (28). This indicates that putting the emphasis on the caries prevention and teeth preservation should be a continuous public health agenda of greatest importance. Furthermore, the gingival inflammation is associated with the plaque build-up and presents strong indicator of the unsatisfactory oral hygiene maintenance $(29,30)$, and resolving problems of the excessive plaque accumulation is important for the upcoming orthodontic treatment. Adverse effects of orthodontic therapy, like white spot lesions and gingivitis, can be avoided by reduction of plaque accumulation (31).

The limitation of the study is in its sample, because the study described prevalence for the capital's schoolchildren population, and the findings from rural areas and other regions could differ from here presented data. Therefore, the conclusions can be made only for Zagreb's schoolchildren population, and not for the whole country. However, the strength lies in the fact that the agreement between DAI and ICON indices does not depend on type of the area inspected.

Taking all above-mentioned reasons into account, the intent of this comprehensive study was to initiate changes within the Croatian public health system. As a result of this investigation, the threshold occlusal traits for enrolment into orthodontic treatment were set. The evaluation of the changes made should be conducted in the future. Also, stronger emphasis should be put on caries and gingivitis prevention, as a public health goal which is important for a persons' own general health perception.

Evaluation of the changes made within the healthcare system would be necessary in a future similar study. The determination of the orthodontic treatment need is complex and future studies should include several evaluation methods, because different indices have their own special grading and are not in perfect agreement with each other.

\section{CONCLUSIONS}

The DAI and ICON indices have moderate agreement in assessment of malocclusion severity scores. One third of all schoolchildren have gingivitis, and half of them have caries which would postpone enrolment in orthodontic treatment. The degree of malocclusion severity is not the sole factor in public health orthodontic treatment need analysis; dental and periodontal health, co-operability and willingness to undergo orthodontic treatment should also be taken into account.

\section{CONFLICTS OF INTEREST}

The authors declare that no conflicts of interest exist.

\section{FUNDING}

The study was financed by the project "Reorganization and modernization of orthodontic services in the City of Zagreb based on evaluation of orthodontic treatment needs of schoolchildren, an epidemiological survey and quality assessment" supported by Zagreb City Municipal grant and Croatian Ministry of Science, Education and Sport Grant. The head of both projects was professor Mladen Šlaj; and University of Rijeka research project "13.06.2.1.53 Predictors for success of orthodontic treatment in children and adolescents", principal investigator Stjepan Špalj.

\section{ETHICAL APPROVAL}

Received from the Croatian Ministry of Science, Education and Sports, the Ministry of Health and Social Affairs, and the Ethics Committee of the Zagreb University School of Dental Medicine.

\section{REFERENCES}

1. Cons N, Jenny J, Kohout F. DAl: the dental aesthetic index. lowa City: College of Dentistry, University of lowa, 1986.

2. Richmond S, Shaw WC, O'Brien KD, Buchanan IB, Jones R, Stephens $C D$, et al. The development of the PAR index (Peer Assessment Rating): reliability and validity. Eur J Orthod. 1992;14:125-39. doi: 10.1093/ejo/14.2.125

3. Daniels $\mathrm{C}$, Richmond S. The development of the index of complexity, outcome, and need (ICON). J Orthod. 2000;27:149-62. doi: 10.1093/ ortho/27.2.149

4. Brook PH, Shaw WC. The development of an index of orthodontic treatment priority. Eur J Orthod. 1989;11:309-20. doi: 10.1093/ oxfordjournals.ejo.a035999

5. International collaboration study of oral health outcomes (ICS II), document 2: oral data collection and examination criteria. Geneva: World Health Organization, 1989.

6. Chen $M$, Andersen RM, Barmes DE, Leclercq MH, Lyttlee CS. Comparing oral health systems: a second international collaborative study. Geneva: World Health Organization, 1997.

7. Continuous improvement of oral health in the 21 st century-the approach of the WHO global oral health programme. Geneva: World Health Organization, 2003.

8. Burden DJ, Pine CM, Burnside G. Modified IOTN: an orthodontic treatment need index for use in oral health surveys. Community Dent Oral Epidemiol. 2001;29:220-5. doi: 10.1034/j.16000528.2001.290308.x

9. Bellot-Arcís C, Montiel-Company JM, Almerich-Silla JM. Orthodontic treatment need: an epidemiological approach. In: Bourzgui F, editor. Orthodontics - basic aspects and clinical considerations. Rijeka: InTech, 2012:3-28. 
10. Johnson $M$, Harkness $M$, Crowther P, Herbison P. A comparison of two methods of assessing orthodontic treatment need in the mixed dentition: DAl and IOTN. Aust Orthod J. 2000;16:82-7.

11. Beglin FM, Firestone AR, Vig KWL, Beck FM, Kuthy RA, Wade D. A comparison of the reliability and validity of 3 occlusal indexes of orthodontic treatment need. Am J Orthod Dentofacial Orthop. 2001;120:240-6. doi: 10.1067/mod.2001.116401

12. Onyeaso CO, Begole EA. Relationship between index of complexity, outcome and need, dental aesthetic index, peer assessment rating index, and American Board of Orthodontics objective grading system. Am J Orthod Dentofacial Orthop. 2007;131:248-52. doi: 10.1016/j. ajodo.2005.04.045

13. Onyeaso CO. Orthodontic treatment complexity and need in a group of Nigerian patients: the relationship between the dental aesthetic index (DAI) and the index of complexity, outcome, and need (ICON). J Contemp Dent Pract. 2007;8:37-44.

14. Ovsenik M, Primozic J. Evaluation of 3 occlusal indexes: Eismann index, Eismann-Farcnik index, and index of orthodontic treatment need. Am J Orthod Dentofacial Orthop. 2007;131:496-503. doi: 10.1016/j.ajodo.2006.01.028

15. Fox NA, Daniels C, Gilgrass T. A comparison of the index of complexity outcome and need (ICON) with the peer assessment rating (PAR) and the index of orthodontic treatment need (IOTN). Br Dent J. 2002;193:225-30.

16. Firestone AR, Beck FM, Beglin FM, Vig KW. Validity of the index of complexity, outcome and need (ICON) in determining orthodontic treatment need. Angle Orthod. 2002;72:15-20. doi: 10.1043/0003-3219(2002)072<0015:VOTIOC>2.0.CO;2

17. Ovsenik M. Assessment of malocclusion in the permanent dentition: reliability of intraoral measurements. Eur J Orthod. 2007;29:654-9. doi: 10.1093 /ejo/cjm084

18. Reports. Publication no. 8.1.2. and 8.1.3.. Zagreb: Croatian Bureau of Statistics, 2007.

19. Oral health surveys: basic methods. Publication ORH/EPID. Geneva: World Health Organization, 1997.

20. Borzabadi-Farahani A, Borzabadi-Farahani A. Agreement between the index of complexity, outcome, and need and the dental and aesthetic components of the index of orthodontic treatment need. Am J Orthod Dentofacial Orthop. 2011;140:233-8. doi: 10.1016/j. ajodo.2010.09.028

21. Siddiqui TA, Shaikh A, Fida M. Agreement between orthodontist and patients perception using index of orthodontic treatment need. Saudi Dent J. 2014;26:156-65. doi: 10.1016/j.sdentj.2014.03.004

22. Doğan AA, Sari E, Uskun E, Sağlam AM. Comparison of orthodontic treatment need by professionals and parents with different sociodemographic characteristics. Eur J Orthod. 2010;32:672-6. doi: 10.1093/ejo/cjp161

23. Spalj S, Slaj M, Varga S, Strujic M, Slaj M. Perception of orthodontic treatment need in children and adolescents. Eur J Orthod. 2010;32:387-94. doi: 10.1093/ejo/cjp101

24. Spalj S, Slaj M, Athanasiou AE, Govorko DK, Slaj M. The unmet orthodontic treatment need of adolescents and influencing factors for not seeking orthodontic therapy. Coll Antropol. 2014;38:173-80.

25. Tadić K, Katić V, Špalj S. Caries experience of the patients referred for an orthodontic consultation. Acta Stomatol Croat. 2018;52:12331. doi: $10.15644 /$ asc52/2/5

26. Luzzi V, Fabbrizi M, Coloni C, Mastrantoni C, Mirra C, Bossù M, et al. Experience of dental caries and its effects on early dental occlusion: a descriptive study. Ann Stomatol. 2011;2:13-8.

27. Al-Nimri K, Al-Jundi S, Kharashgah G. The effect of a four-year caries prevention programme started at six-years of age on crowding in the early permanent dentition. Eur J Paediatr Dent. 2010;11:6-8.

28. Ranfl M, Zaletel-Kragelj L. Assessment of the association between dentate status and self rated general health. Zdr Varst. 2017; 56:131-9. doi: 10.1515/sjph-2017-0017

29. Gastel JV, Quirynen M, Teughe W, Coucke W, Carels C. Longitudinal changes in microbiology and clinical periodontal variables after placement of fixed orthodontic appliances. J Periodontol. 2008;79:2078-86. doi: 10.1902/jop.2008.080153

30. Coatoam GW, Behrents RG, Bissada NF. The width of keratinized gingiva during orthodontic treatment: its significance and impact on periodontal status. J Periodontol. 1981;52:307-13. doi: 10.1902/ jop.1981.52.6.307

31. Rego RO, Oliveira CA, dos Santos-Pinto A, Jordan SF, Zambon JJ, Cirelli JA, et al. Clinical and microbiological studies of children and adolescents receiving orthodontic treatment. Am J Dent. 2010;23:317-23. 